\title{
Certain Biological Effects of Thermocline Shifts
}

\author{
(Observations from Lake West Okoboji, Iowa). \\ JOHN E. BARDACH ${ }^{(1)}$ \\ Department of Fisheries, University of Michigan
}

\section{INTRODUCTION}

Some morphometric and limnological features of Lake West Okoboji, one of a number of glacial lakes in Northwestern Iowa, have been described by BIRGE and JUDAY (1920); STROMSTEN (1927) extended these observations by following variations in summer temperatures through several years and JAHN (1939) also drew attention to changes which occurred in the depth and the location of the thermocline. During the summers of 1950, 1951, and 1953, I was in charge of hydrobiological research at the Iowa Lakeside Laboratory, where the previous investigations had been conducted. During these years special attention was given to the effect of variations in summer temperatures and oxygen conditions on the distribution of certain fish and on some bottom invertebrates.

\section{DESCRIPTION OF THE LAKE:}

Lake West Okoboji, (Lat. $43.35^{\circ} \mathrm{N}$, Long. $95.13^{\circ} \mathrm{W}$ ), is one of a series of lakes formed at the retreat of the Mankato Lobe of the Wisconsin glaciation. A deep central trough suggests ist origin from a preglacial river.

The General Features of Lake West Okoboji, Iowa( ${ }^{2}$ )

Length:

$5.46 \mathrm{mi} .(8.79 \mathrm{~km}$.)

Greatest breadth:

$2.48 \mathrm{mi}$. $(4.57 \mathrm{~km}$.)

1) Formerly Iowa State Teachers College and Iowa Lakeside Laboratory

2) From Birge and Juday, 1920 


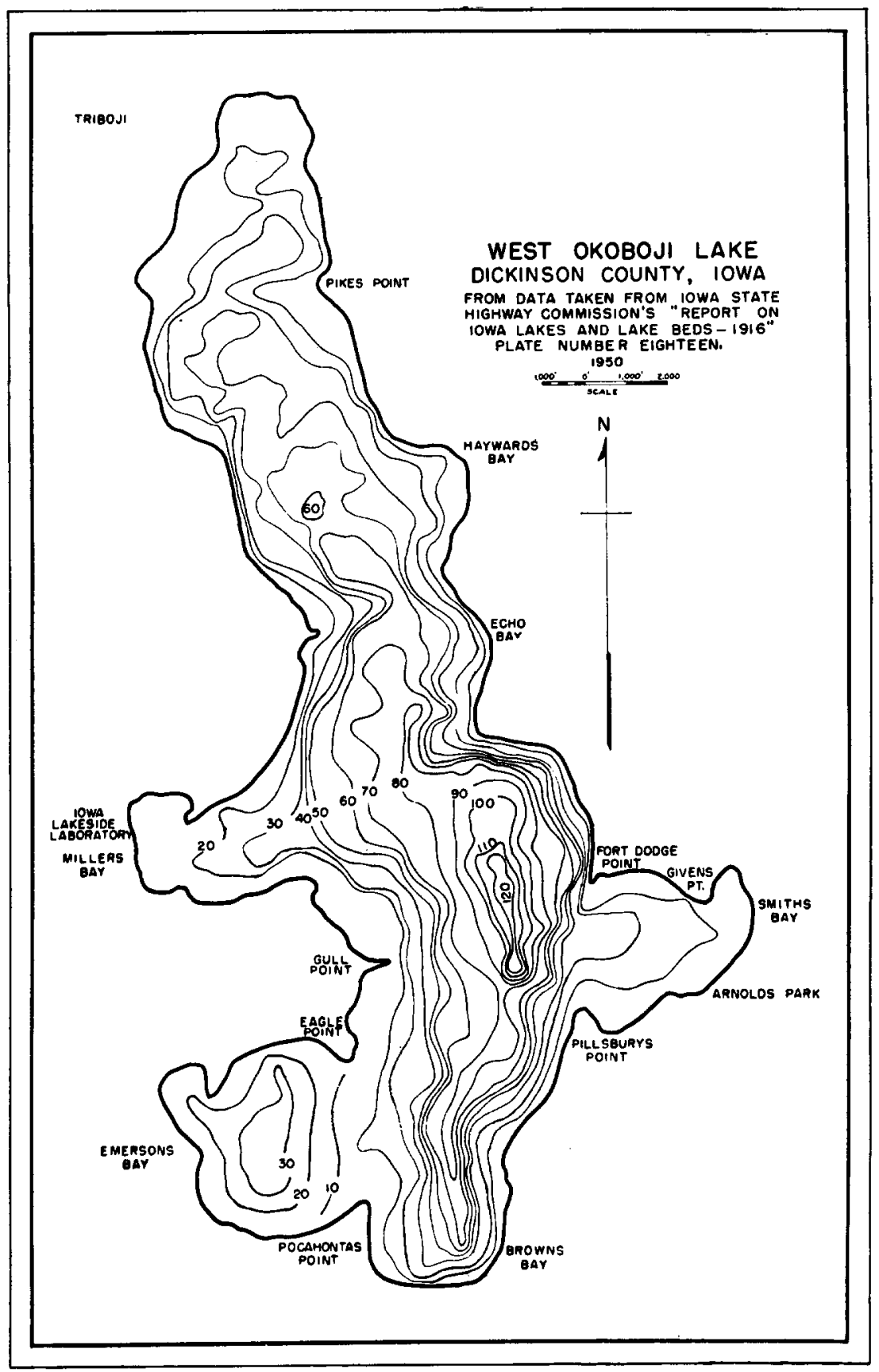

Fig. 1.

Contour Map of Lake West Okoboji, Iowa (depth indicated in feet). 
Mean breadth:

Direction of main axis:

Greatest depth:

Mean depth

Volume

$246,340,000$ cu. yds.

$188,340,000$ cu. $\mathrm{m}$.

Length of shore line

Shore development

Volume development
$1.09 \mathrm{mi} .(1.72 \mathrm{~km}$.)

North and South

$135.0 \mathrm{ft} . \quad(41.0 \mathrm{~m}$.

$40.4 \mathrm{ft} . \quad(12.3 \mathrm{~m}$.

$18.2 \mathrm{mi} . \quad(29.3 \mathrm{~km}$.)

2.13

0.92

A volume development value under 1.00 suggests that the lake has relatively little deep water; its maximum depth, however, is considerable for an Iowa lake. Bays and littoral areas have a gently sloping bottom; in the deeper parts the slope increases rapidly to a pronouncedly V shaped profile (Fig. 1). Lake West Okoboji, typically eutrophic, is prone to yearly blooms of blue-green algae, which are part of a rich flora (Prescott, 1931). Its fish fauna is dominated by the perch family, yellow perch (Perca flavescens Mitchill) being the most abundant fish, but closely followed by the walleye or yellow pikeperch (Stizostideon vitreum vitreum Mitchill). Centrarchids are also plentiful but they are usually restricted to the shallower bay regions, at least during mid-summer, the time which interests us here.

\section{MATERIALS AND METHODS:}

Temperature records were obtained with electrical resistance thermometers and, since 1951, a bathythermograph was also used. Oxygen determinations were made according to the standard Winkler method (Amer. Pub. Health Assoc., 1946).

Experimental gill nets of 25 feet. (7.5) m. length and $5 \mathrm{ft}$. $(1.5 \mathrm{~m}$.) depth with bar-mesh sized of 3/4-, 1 - and $1 \frac{1}{4}$ inches $(1.95,2.54$ and $3.18 \mathrm{~cm}$.) respectively, were used for ascertaining the distribution of the perch. Similar nets, but of $2 \frac{1}{2}-$ and 3-inch mesh $(6.3 ; 7.62 \mathrm{~cm})$ were set for the larger fish such as the pike-perch, the northern pike (Esox lucius L.) and others. The nets were set on the bottom at certain marked or triangulated stations at varying depths along several transects through the lake, they were lifted at 2 or 3 hour intervals. 138 nets were set in 1950, 131 in 1951 and 76 in 1953, making a total of 345 short gill nets set. 
An Ekman dredge of 6 inches sidelength $(15.2 \mathrm{~cm} . ;$ area sq. $\mathrm{cm}$.) was employed for collecting the bottom fauna. Here also certain transects had been established and samples were taken there in triplicate at depth intervals of 6.5 to 15 feet ( 2 to $5 \mathrm{~m}$.). The various bottom organisms were counted and their net volume was determined by water displacement.

\section{ANNUAL VARIATIONS IN MIDSUMMER WATER TEMPERATURES}

The beginning of May usually found the lake in a homothermous condition; between May 15 and June 1 stratification began but the temperature below $30 \mathrm{~m}$. had reached $10^{\circ} \mathrm{C}$. by then. During the summer the hypolimnion further warmed up to 12 to $13^{\circ} \mathrm{C}$. This temperature is relatively high for a stratified lake of such depth and this latitude, especially when the thermocline is located at around $12 \mathrm{~m}$., as was characteristic for Lake West Okoboji. This level corresponded to the mean depth of the lake, leaving only a small hypolimnion which then reached a relatively high temperature in a short time.

In some years (e.g. 1925, 1926, and 1950) with unusually heavy winds during some warm periods in the late spring and early summer, a thermocline did not form until very late in the season and it was then situated considerably deeper than in ordinary years such as 1919, $1923,1936,1938,1951$, and 1953. In the seasons of no, or late, thermal stratification, and they appear to have been the exception rather than the rule between 1919 and 1953, the temperature changed very gradually down to about $20 \mathrm{~m}$. and therefore, there was a similarly slow transition of other environmental variables such as the concentration of dissolved gases and $\mathrm{pH}$. In these years, which I shall call „Late Thermocline Years", there was, in mid-August, a difference of only $6-7^{\circ} \mathrm{C}$., between the surface and bottom water which would warm up to 17 or $18^{\circ} \mathrm{C}$. At the end of such an unusual summer the lake was in stable layers of different density with a much larger epilimnion than usual. These layers lasted only a few weeks, compared to the three months or more when summer stratification was established early (Table 1, Fig. 2.). 
Table 1

Comparison between mid-August water temperatures of Lake West Okoboji (Iowa)

during summers with early and late thermoclines.

Temperatures in

7 early thermocline years

Temperatures in

3 late thermocline years

$\begin{array}{lll}\text { Depth in } \mathrm{m} \quad \text { Low } \quad \begin{array}{l}\text { Mean } \\ \mathrm{C}^{\circ}\end{array} & \text { High }\end{array}$

Low Mean High

$\begin{array}{llll}\text { Surface } & 23.8 & 24.4 & 25.0\end{array}$

$\begin{array}{lll}21.3 & 22.7 & 24.1\end{array}$

$\begin{array}{llll}2 & 23.8 & 24.4 & 25.0\end{array}$

$\begin{array}{lll}23.7 & 24.3 & 24.9\end{array}$

$\begin{array}{lll}21.3 & 22.1 & 23.0\end{array}$

$\begin{array}{llll}4 & 23.7 & 24.3 & 24.9 \\ 6 & 23.6 & 24.3 & 24.9\end{array}$

$\begin{array}{lll}21.3 & 21.8 & 22.3\end{array}$

$\begin{array}{llll}8 & 23.6 & 24.3 & 24.9\end{array}$

$21.1 \quad 27.6 \quad 22.0$

$\begin{array}{lll}21.1 & 21.3 & 21.6\end{array}$

$\begin{array}{llll}10 & 23.5 & 24.1 & 24.7\end{array}$

$\begin{array}{llll}12 & 15.2 & 19.1 & 23.0\end{array}$

$\begin{array}{llll}14 & 14.0 & 17.7 & 21.5\end{array}$

$\begin{array}{llll}16 & 12.2 & 15.8 & 19.5\end{array}$

$\begin{array}{llll}18 & 11.6 & 13.8 & 16.1\end{array}$

$\begin{array}{llll}20 & 11.3 & 12.8 & 14.4\end{array}$

$\begin{array}{llll}22 & 10.6 & 12.4 & 14.2\end{array}$

$21.0 \quad 21.3 \quad 21.6$

$20.6 \quad 20.9 \quad 21.1$

$\begin{array}{lll}20.9 & 20.4 & 20.7\end{array}$

$\begin{array}{lll}19.1 & 19.5 & 19.8\end{array}$

$\begin{array}{lll}18.6 & 18.7 & 18.8\end{array}$

$\begin{array}{lll}17.4 & 17.8 & 18.1\end{array}$

$\begin{array}{llll}25 & 10.6 & 12.3 & 14.0\end{array}$

$\begin{array}{llll}30 & 10.3 & 12.0 & 13.8\end{array}$

$\begin{array}{llll}35 & 10.3 & 11.9 & 13.5\end{array}$

$\begin{array}{llll}40 & 10.3 & 11.9 & 13.5\end{array}$

$\begin{array}{lll}16.6 & 16.9 & 17.1\end{array}$

$\begin{array}{lll}15.8 & 16.2 & 17.0\end{array}$

$\begin{array}{lll}15.0 & 16.0 & 16.8\end{array}$

$\begin{array}{lll}14.5 & 15.3 & 16.4\end{array}$

$\begin{array}{lll}14.3 & 15.2 & 16.2\end{array}$ 


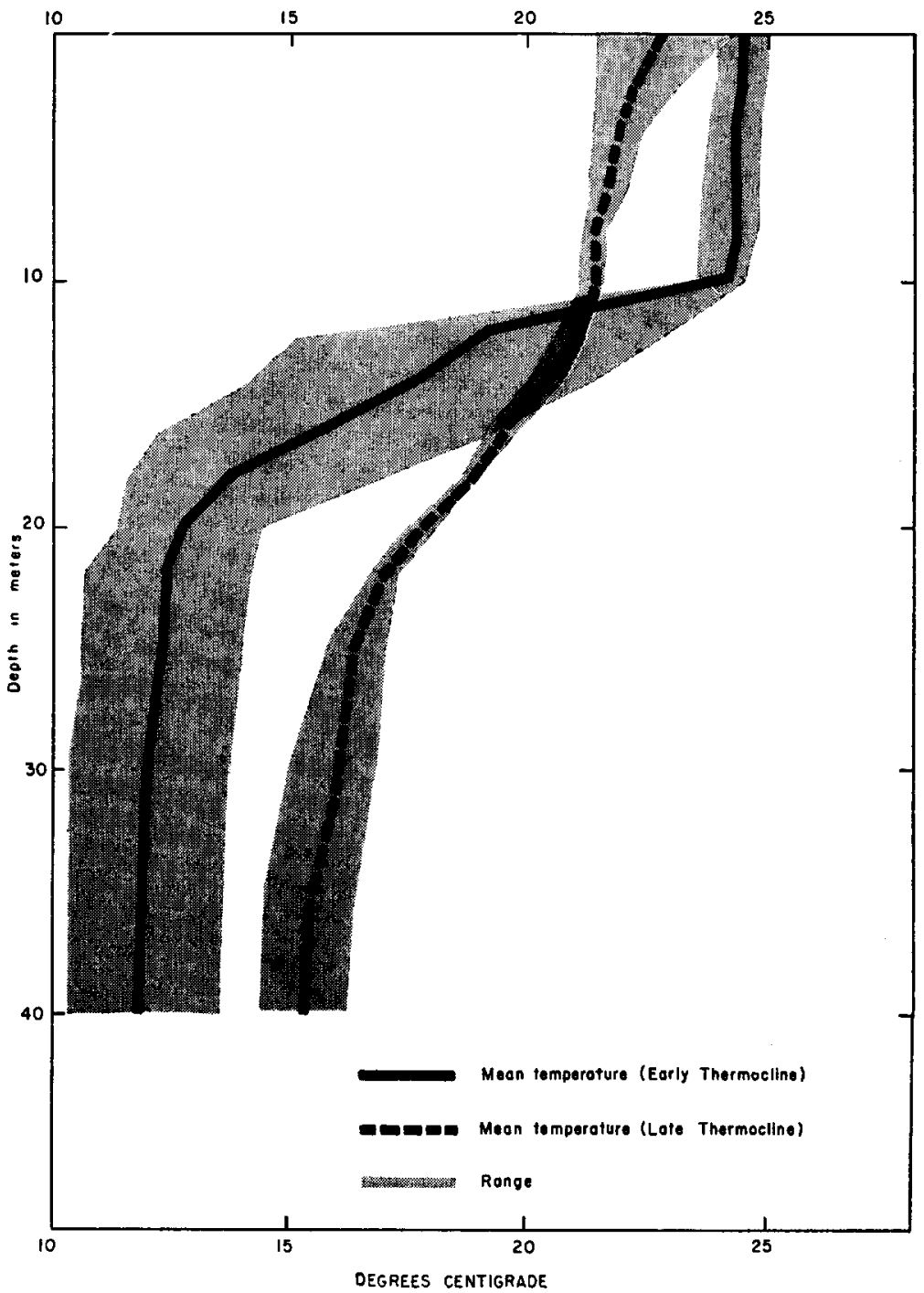

Fig. 2.

Mid-August Water Temperatures of Lake West Okoboji, Iowa, in Summers with Early and Late Thermoclines.

The contrast between the two types of summer conditions is further shown by the distribution of dissolved oxygen in the lake (Table 2, Fig. 3). 


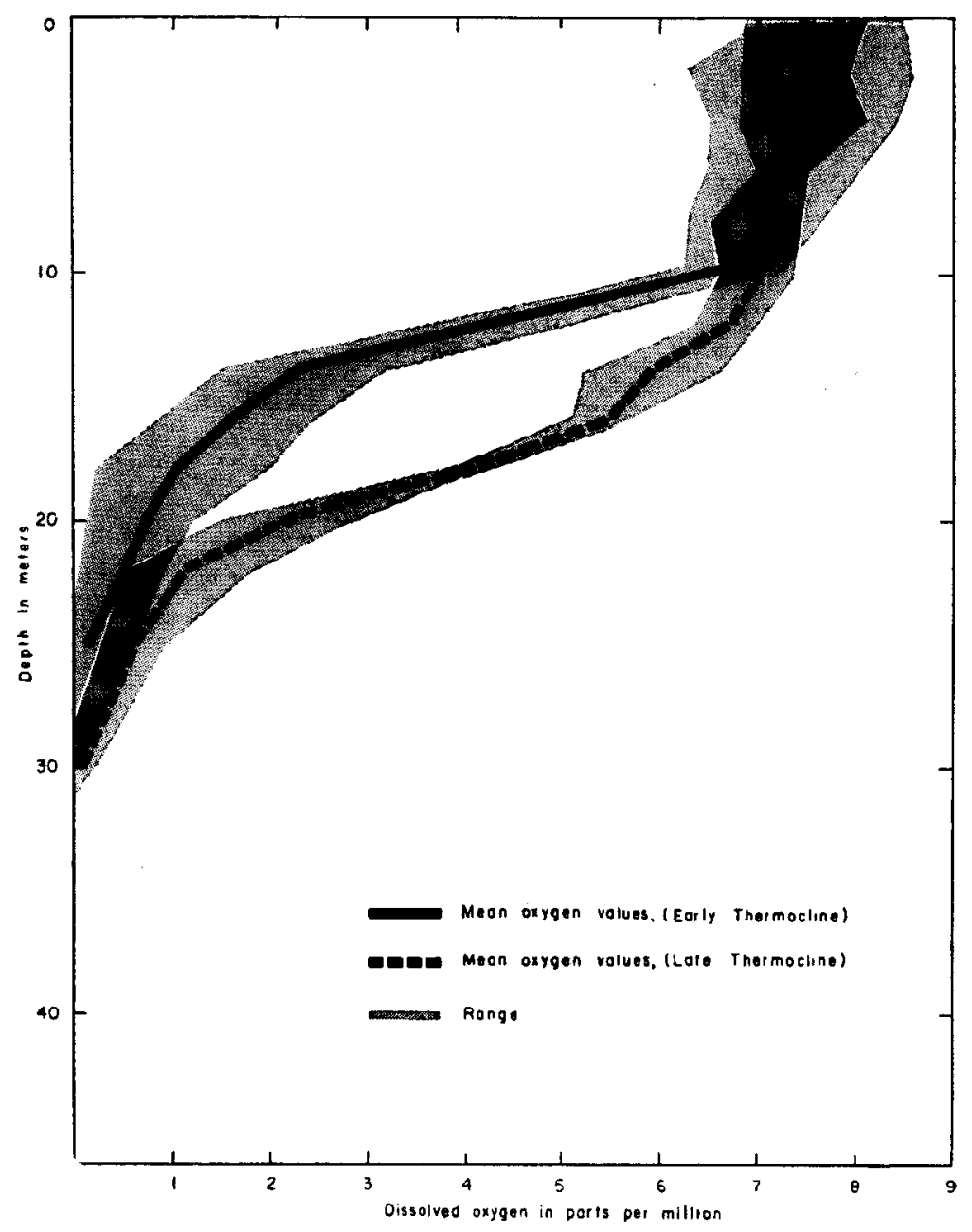

Fig. 3.

Mid-August Oxygen Distribution in Lake West Okoboji, Iowa, in Summers with and Early Late Thermoclines. 
Table 2

Comparison between mid-August oxygen distribution at various depths in

Lake West Okoboji (Iowa)

during summers with early and late thermoclines

\begin{tabular}{clcccccc}
\multicolumn{3}{c}{} & \multicolumn{3}{l}{$\begin{array}{l}\text { Parts per million of oxy- } \\
\text { gen in 7 early thermocli- } \\
\text { ne years }\end{array}$} & \multicolumn{4}{l}{$\begin{array}{l}\text { Parts per million of oxy- } \\
\text { gen in 3 late thermocli- } \\
\text { ne years }\end{array}$} \\
$\begin{array}{c}\text { Depth in m } \\
\text { Surface }\end{array}$ & Low & Mean & High & Low & Mean & High \\
2 & 7.1 & 7.8 & 8.6 & 6.9 & 7.5 & 8.1 \\
4 & 6.3 & 7.5 & 8.7 & 6.9 & 7.5 & 8.0 \\
6 & 6.5 & 7.5 & 8.5 & 6.9 & 7.5 & 8.2 \\
8 & 6.5 & 7.3 & 8.1 & 7.0 & 7.3 & 7.5 \\
10 & 6.3 & 7.0 & 7.7 & 6.7 & 7.2 & 7.5 \\
12 & 6.3 & 6.8 & 7.3 & 6.7 & 7.1 & 7.4 \\
14 & 3.7 & 4.5 & 5.4 & 6.4 & 6.8 & 7.1 \\
16 & 1.5 & 2.3 & 3.2 & 5.1 & 5.9 & 6.7 \\
18 & 0.92 & 1.6 & 2.4 & 5.1 & 5.5 & 5.8 \\
20 & 0.20 & 1.0 & 2.0 & 3.8 & 4.1 & 4.3 \\
22 & 0.20 & 0.7 & 1.2 & 1.4 & 2.2 & 2.9 \\
25 & \pm 0.5 & & & 0.5 & 1.1 & 1.8 \\
30 & \pm 0.15 & & & 0.2 & 0.5 & 0.9 \\
35 & 0.00 & & & & 0.2 & \\
40 & 0.00 & & & & & & 0.0 \\
& 0.00 & & & & & & \\
\end{tabular}

All available oxygen was used up below $27 \mathrm{~m}$. regardless of thermal conditions. The gas tended to disappear by mid-July when there was an early thermocline but the high temperature of the hypolimnion in „Late Thermocline Years", also caused oxygen depletion, apparently making up for the greater depth to which oxygen had been carried. Since the depth of twenty meters represented the limit at which fish were netted in appreciable numbers, summer oxygen conditions at that depth should be compared from year to year.

When there was early layering the temperature fell from $20.5^{\circ} \mathrm{C}$. at $15 \mathrm{~m}$. to $14.5^{\circ} \mathrm{C}$. at $20 \mathrm{~m}$. (e.g.19 23, 1938, 1951, 1953) accompanied by a decline in oxygen from $1.5 \mathrm{ppm}$. to $0.2 \mathrm{ppm}$. before the 1 st of August. When there was a later thermocline (e.g. 1925, 1926, $1950), 1.8$ to $2.5 \mathrm{ppm}$. of dissolved oxygen still existed at $20 \mathrm{~m}$. on or around August 15. This meant that the water just above the bottom mud was 5 degrees warmer and contained about ten times as much oxygen in years of late - than in years of early - stratification (Table 2, Fig. 3).

In some other lakes, such as Douglas Lake, Michigan (WELCH, 1927), and Lake Mendota, Wisconsin (BIRGE and JUDAY 1911) where water temperatures had been taken through many years, variations in the level of the thermocline have also been observed from summer 
to summer. In 1926, for instance, when Lake West Okoboji was not stratified, four of the five individual depressions in Douglas Lake were in a similar condition. Because these other lakes are basin rather than furrowshaped the thickness of the epilimnion did not change as repeatedly or over as wide a range as in Lake West Okoboji and no records were published of the direct effects of these changes on fish distribution.

\section{THE EFFECTS OF LAKE STRATIFICATION ON THE DIEL DISTRIBUTION OF YELLOW PERCH AND OTHER FISH}

In Lake West Okoboji, as in several other lakes, for instance, Lake Mendota, Wisconsin (HASLeR and BARDACH, 1949), and Clear Lake, Iowa (CARLANDER and Cleary, 1949) the bulk of the yellow perch came to the shallows (4-6 m.) at sunset and retreated to the deeper water at sunrise (BROwN and Rosen, 1951). The depth at which the fish were found during the day varied in different years according to temperature and oxygen distribution. (Table 3, Fig. 4).

Table 3

Gill net catches of yellow perch at various depths in Lake West Okoboji, Iowa Number of perch in 100 feet of net per hour

$\begin{array}{ccc}\text { Depth in } \mathrm{m} . & \begin{array}{c}\text { Early Thermocline } \\ \text { years }(1951,1953)\end{array} & \begin{array}{c}\text { Late Thermocline } \\ \text { year }(1950)\end{array} \\ \text { Surface } & - & - \\ 2 & - & - \\ 4 & 14.5 & 8.7 \\ 6 & 12.76 & 8.5 \\ 8 & 5.0 & - \\ 10 & 7.4 & 4.6 \\ 12 & 7.2 & - \\ 14 & 3.5 & 11.3 \\ 16 & 3.1 & - \\ 18 & 1.7 & 10.5 \\ 20 & 0 & 9.7 \\ 22 & 0 & 3.2 \\ 25 & 0 & 0.4 \\ 30 & 0 & 0 \\ 35 & 0 & 0\end{array}$




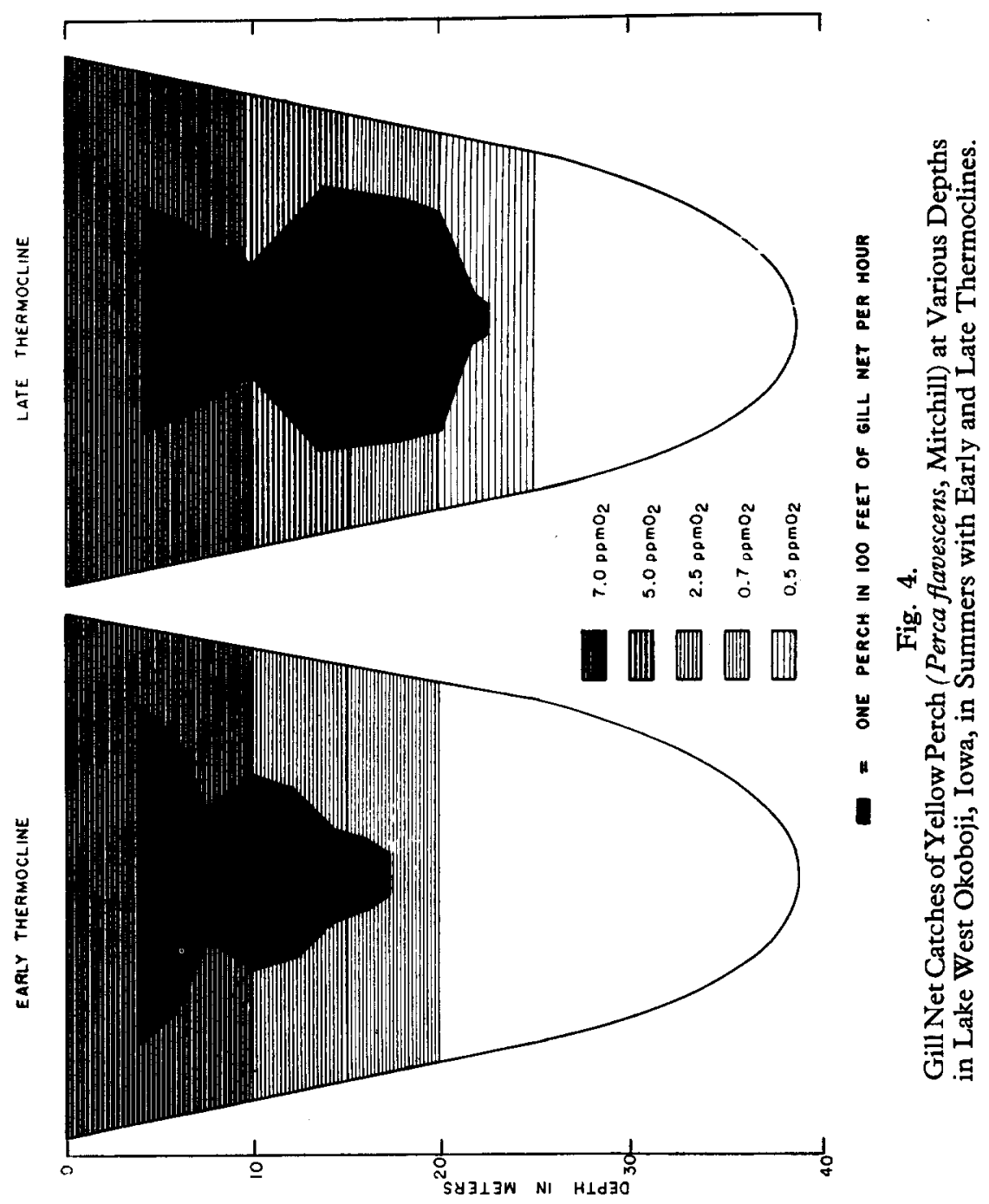

In the „Late Thermocline Years" they foraged for bottom organisms as deep as $20 \mathrm{~m}$. and beyond. Thus gill nets set at that depth during the daylight hours caught the largest numbers of perch. In most years, however, the water at $20 \mathrm{~m}$. was essentially without oxygen and the perch were found between 10 and $12 \mathrm{~m}$. During the summer nights they approached the shore under any conditions.

When the fish fed at $20 \mathrm{~m}$. during the day, $45 \%$ of their food, 
by volume, was made up of tendipedid larvae. In the years when they spent their days in shallower water, plankton and forage fishes made up the bulk of their stomach contents.

The pike-perch showed a distribution pattern similar to that of the perch; they spent the day in deeper water and came to shallower regions at night. It was interesting to note that they did not approach the shore as closely as the perch during the summer nights, staying largely in 7 to $10 \mathrm{~m}$. of water. Thus the movements of pelagic fish involved but little change in depth in summers of early stratification when they rarely went deeper than $15 \mathrm{~m}$.

The large centrarchids, the largemouth bass, (Micropterus salmoides salmoides) and the small mouth bass (Micropterus dolomieu dolomieu) as well as the Northern pike have not been observed to follow a comparable schedule. While they moved about more during the twilight hours, they did not seem to leave the shallower regions to any extent and they were not observed to shift regularly between deeper and shallower water.

A correlation between environmental variables and the distribution of the percid fished became obvious with the striking changes in the net catches at various depths in the different years. (Fig. 4).

PeARSE and ACHTENBerg (1921) observed that oxygen lack limited the depth distribution of perch and HASLER and VILLEMONTE (1953) reported, from Lake Mendota, that the fish were restricted mostly to the thermocline region during the daylight hours. The perch in Lake West Okoboji followed a similar behavior pattern but the wide range of their lower limit of distribution represented another clear-cut field record of the dependence of fish on a certain minimum level of oxygen tension.

I assume two physiological limitations as the key to the behavior of the perch: they are capable of contracting an oxygen debt, enabling them to spend some time in water with very little or no oxygen. When Pearse (1918) lowered perch into the hypolimnion in cages they survived for $1-2$ hours and during that time the relative amounts of oxygen in their swim bladders decreased substantially. A look at the total volume of oxygen in the swim bladder on one hand and the oxygen requirements of the animal on the other suggested that this reservoir of oxygen could not enable the fish to forage on the bottom under unsuitable oxygen conditions, though this was advanced by Pearse (1918). It was calculated that a perch of $200 \mathrm{~g}$. might satisfy his oxygen demand from the swim bladder for a total of 5-10 minutes at best (HASLER and MEYER, 1942) and KhALIL's experiments (1937) verified these calculations. This pointed to the existence of a well developed physiological mechanism for contracting an oxygen debt. 
Balanced against this ability to dip into the hypolimnion there is a limitation on the vertical movement imposed on the physoclistous fish by the presence of a closed swimbladder (JoNEs, 1952). The rate of pressure adjustment of which the fish is capable might make it difficult for it to reach the zone where bottom forage is profitable within the time limits it has available because it has to balance between respiratory and pressure restrictions.

It has already been mentioned that substantial bottom feeding occurred only during the „Late Thermocline Year" when the water contained some oxygen at $20 \mathrm{~m}$. and beyond.

This interplay of physiological and ecological factors made the daily pattern of activity appear different under different environmental conditions. Thus late and deep layering of the water brought with it a pronounced „diel" movement of fishes which included vertical displacement. In the other, more numerous years, when an early density seal led to rapid reduction of oxygen in the hypolimnion, the fish did not change their horizontal level appreciably from day to night though they still could be followed in an on- and off-shore movement.

Such changes in fish distribution from one year to the next indicate that one should not only note the time of the year and the temperature and oxygen conditions in a body of water where the distribution of fish is under investigation, but also take into account the time of the sampling day.

\section{THE EFFECT OF STRATIFICATION ON SOME LARVAE OF THE GENUS TENDIPES}

As in many other lakes, certain bottom organisms outnumbered all others in some zones of Lake West Okoboji (BARDACH, MORRILL, and GAMBONY, 1951). Between 10 to $15 \mathrm{~m}$. the tendipedid larvae per square meter increased and reached a peak near the $20 \mathrm{~m}$.-contour (Table 4, Fig. 5). In „Late Thermocline” 1950, 2.3 ppm. of oxygen were still available there in mid-August but in the summers of 1951 and 1953 with different temperature and oxygen values, when samples were again taken at the same stations, the picture of distribution of the large midge larvae, at least (Tendipes plumosus and $T$. decorus), was quite different (Table 4, Fig. 5). It is therefore not surprising to find here, as in the case of the fish, a correlation between environmental variables and animal distribution reflected in the significantly different numbers of bottom organisms at the same sampling stations in different years. 
Table 4

Mid-summer density of Tendipes larvae at various depths in Lake West Okoboji, Iowa

Wet volume in cubiccentimeters per liter

\begin{tabular}{cccc} 
& \multicolumn{2}{l}{$\begin{array}{l}\text { Early Thermocline } \\
\text { Years }\end{array}$} & $\begin{array}{l}\text { Late Thermocline } \\
\text { Years }\end{array}$ \\
$\begin{array}{c}\text { Depth in m. } \\
5\end{array}$ & 1953 & 1951 & 1950 \\
7 & - & - & - \\
10 & 2.0 & & 1.6 \\
13 & 4. & 7.5 & 11.4 \\
15 & 13.8 & - & - \\
17 & 10.3 & 7.5 & 22.1 \\
20 & 6.4 & 11.7 & - \\
24 & 5.2 & - & 35.8 \\
25 & 6.0 & 6.1 & 12.4 \\
30 & 3.0 & 4.0 & 10.0 \\
& 0.5 & 0.7 & 6.1
\end{tabular}

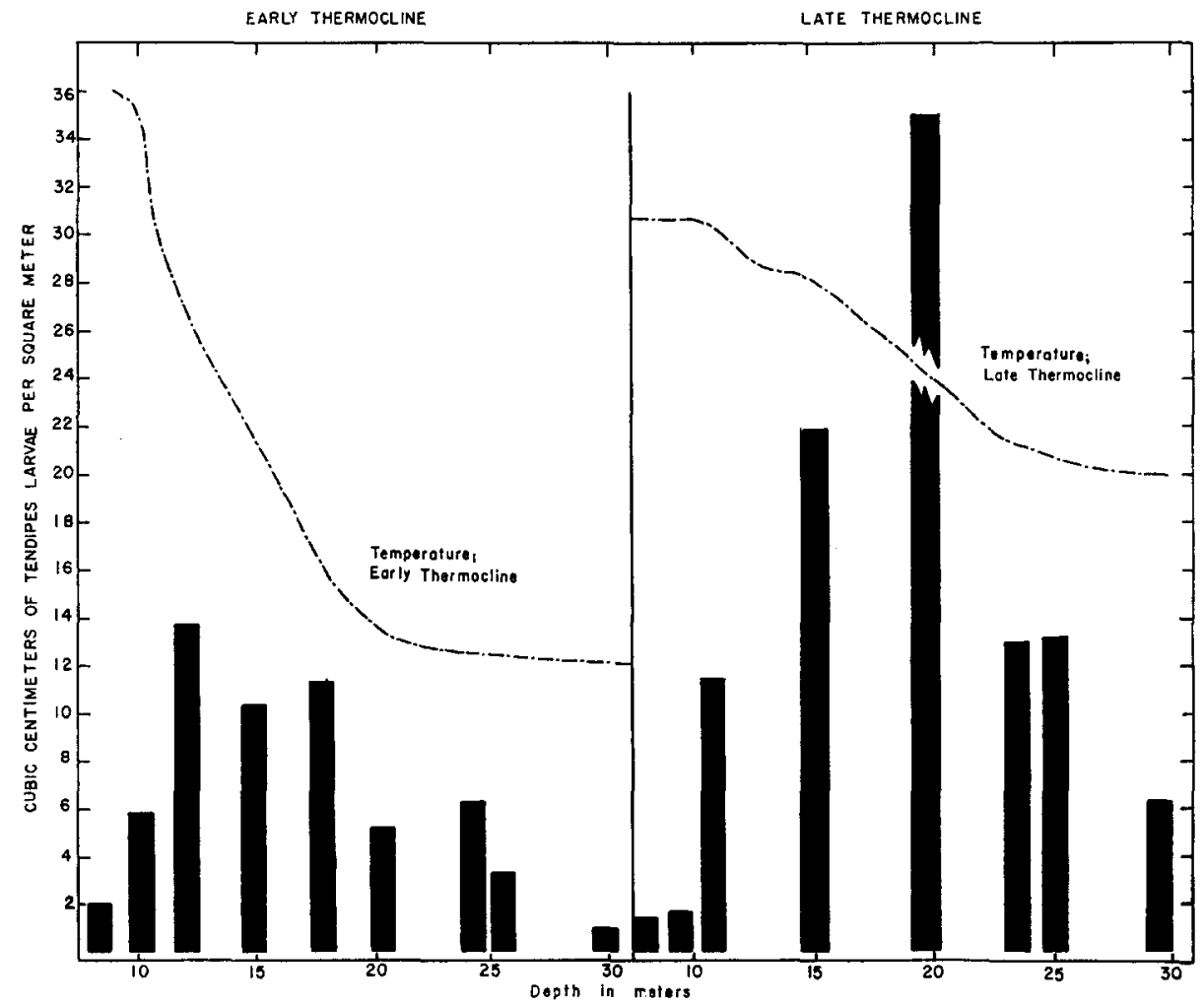

Fig. 5.

Mid-summer Density of Tendipes Larvae in Lake West Okoboji, Iowa, in Summers with Early and Late Thermoclines. 
The zonation and distribution of the profundal bottom fauna has been studied in a great number of lakes. Various environmental factors that may determine this distribution have been discussed by EGGLETON (1931) and others. It is still not clear, however, in what manner concentration zones of midge larvae arise. It is unlikely that a large-scale movement from shallower or deeper water could occur. It is fairly certain, though, that the depth at which these peaks in distribution may be found represent regions of very suitable, if not optimal environmental conditions, the concentration of dissolved oxygen again being a key-factor (EGGLETON, 1931).

Such an accumulation of essentially stationary bottom organisms might be explained by the fluctuations of the thermocline. Besides temperature and oxygen levels in Lake West Okoboji which rose and fell in response to climatic conditions, these shifts also affected the depth to which the Lake was mixed by the wind. It could be a coincidence that these levels, around $20 \mathrm{~m}$. in one and $10-12 \mathrm{~m}$. in the other years, also clearly marked the greatest abundance of midge larvae.

Tendipes plumosus and decorus both emerged throughout the summer but swarmed in greatest numbers in middle- and late-August. Little is known about the specific gravity of eggs after deposition. It may well be that the vertical circulation pattern was responsible for piling up large numbers of eggs on the bottom at certain levels in the lake in such a manner that they settled out at the lower border of winddriven currents where the most noticeable rise in density occurred and where therefore the flotation power of the water changed most appreciably.

The wind-induced circulation of the lake has, as one of its features, the return of water from the downwind end of the lake at the bottom of the epilimnion (BRYSON and SUOMI, 1952). Eddies and countercurrents occur in the regions of density discontinuity and these turbulences are further increased by internal standing waves. (MORTIMER, 1952).

In ,Late Thermocline Years" the water was under the direct influence of the wind, and of lower density, to a much greater depth than in other years. This may have provided a larger volume from which the eggs could settle out before they would encounter water of higher density. It is intended to do further sampling with this possibility in mind because it could explain the yearly shifts in midge larvae if any single factor can. In addition, the greater number of larvae may also have been partly due to the higher bottom temperature when the circulation extended to $20 \mathrm{~m}$.

Lake West Okoboji provided an experimental situation where temperature profiles changed substantially from year to year. Though 
these changes could, obviously, not be predicted, they had a profound effect on the behavior and the distribution of some members of the lake biota. The pike-perch and the yellow perch among the fish, and the larvae of two species of Tendipes were demonstrably influenced, though many phases of their behavior are not completely understood. Further studies along those lines are intended since other organisms were probably similarly affected.

\section{SUMMARY}

Under the influence of variable climatic conditions in the spring and due to the peculiar shape of its basin, Lake West Okoboji, Iowa, showed considerable variations in mid-summer temperatures from year to year. The lake either became stratified early in June or stayed mixed until some time in August. When the thermocline formed early between 10-12 m., as usual, it left a deep hypolimnion of relatively small volume. In such years, yellow perch and other fish had weak diel movements from 12 to $5 \mathrm{~m}$. and back. When, in other years, the epilimnion was deep and ample oxygen extended to $20 \mathrm{~m}$, the same fish showed more pronounced on- and off-shore migrations and spent part of the day at the $20 \mathrm{~m}$. contour where they foraged on the tendipedid larvae which reached greatest abundance there. In years of early stratification, however, when the midge larvae were fewer and showed some concentration between 10 and $12 \mathrm{~m}$., they were not a preferred item in the diet of the perch.

The behavior of the fish is discussed with physiological limitations in mind and their ability to contract an oxygen debt as well as the adjustment of swim bladder volume are considered as critical factors. Some speculation is made about the possible role of density-dependent water movements on the distribution of midge larvae; the concentration zones of Tendipes larvae coincided closely with the depth to which the wind-driven circulation extended and where water density shifted most pronouncedly. 


\section{LITERATURE CITED:}

American Public Health Association. - 1946 - Standard Methods for the examination of water and sewage, 9th ed. New York, Amer. Publ. Health Assn.

Bardach, J. E., John Morrill and Frank Cambony, - 1951. - Preliminary report on the distribution of bottom organisms in West Lake Okoboji, Iowa. Proc. Iowa Acad. Sci. 58: 405-414.

Birge, A. E. and Chancey Juday, - 1911. - The inland lakes of Wisconsin. The. dissolved gases of the water and their biological significance. Wis. Geol and Nat. Hist. Surv. Bull. 22: 1-249.

Brown, D. C. and W. G. Rosen, - 1951. - A progress report on the study of perch movement in Lake Okoboji, Dickinson County, Iowa. Proc. Iowa Acad. Sci. 58: 423-432.

Carlander, Kenneth D. and Robert E. Cleary, - 1949. - The daily activity patterns of some freshwater fishes. Amer. Midland Nat. 41(2): 447-452

EgGLETON, FrANK E., - 1931. - A limnological study of the profundal bottom fauna of certain freshwater lakes. Ecol. Monogr. 1: 231-332.

Bryson, R. E. and V. E. SuomI, - 1952. The circulation of Lake Mendota. Trans. Amer. Geophys. Union. 33(5): 707-712.

Hasler, ARThur D. and John E. Bardach, - 1949. - Daily migrations of perch in Lake Mendota, Wisconsin. Jour. Wildl. Man. 13(1): 40-51.

HASLER, A. D. and R. K. MEYER, - 1942. - Respiratory responses of normal and castrated goldfish to teleost and mammalian hormones. Jour. Exp. Zool. 91(3): 391-404.

HASLER, A. D. and J. R. VILLEMONTE, 1953. - Observations on the daily movements of fishes. Science. 118 (3064): 321-322.

JAHN, TH. L. and A. B. TAYLOR, - 1939. - The temperature cycle in the Okoboji lakes. Proc. Iowa Acad. Sci. 46: 403-406.

JoNEs, F. R. H., - 1952. - The swimbladder and the vertical movement of teleostean fishes. Jour. Exptl. Biol. 29 (1): 94-109.

KHALIL, Fouad, - 1937. - Die Bedeutung der Schwimmblase fuer die Atmung der Fische. Zeitschr. vergl. Physiol. 25 (2): 256-282.

MORTIMER, C. H., - 1952. - Water movements in lakes during summer stratification; evidence from the distribution of temperature in Windermere. Philos. Trans. Roy. Soc. London. Ser. B. 236: 355-404.

PeArSE, A. S., - 1918. - The habits of fishes of inland lakes. Sci. Monthly, April 1918: 355-361.

Pearse, A. S. and Henriet ta Achtenberg, - 1029. - Habits of yellow perch in Wisconsin lakes. Bull. U.S. Bur. Fish. 36: 279-366.

Prescott, G. W. - Iowa Algae, Univ. Iowa Stud. Nat. Hist. 13: 1-235.

Stromsten, Frank A., - 1928. - Lake Okoboji as a type of aquatic environment. Univ. Iowa Stud. Nat Hist. 12 (5): 1-52.

WELCH, PAUL S. - Limnological investigations on Northern Michigan lakes. Pap. Mich. Acad. Sci. Arts. Lett. 8: 421-451. 